\title{
JLECOV
}

\section{The effect of social media marketing on brand equity and consumer purchasing intention}

\author{
Saadet Sağtaş \\ Dr. Öğr. Üyesi, Çă̆ Üniversitesi, İktisadi ve İdari Bilimler Fakültesi, Türkiye, e-mail: saadetsagtas@cag.edu.tr
}

\begin{abstract}
Social media is one of the internet-based innovations that reach millions of users around the world with its dynamic and mutually interactive structure. Social media is defined as the digitalization of traditional media channels, and has changed the way of interpersonal communication. Social media applications that provide communication and interaction between people have become an important competitive tool for businesses over time. Users of Social Media Applications are increasing day by day and this increase has caused businesses a rush to communicate with their consumers continuously and quickly through social media channels. The purpose of this study is to examine the effect of social media marketing on consumer purchase intention.

In this study, the affect of social media marketing activities on perceived brand equity and purchasing intention has been examined through the developed model. Within the scope of the study, an online survey was conducted with 227 users who have a Facebook account and actively follow any brand profile on Facebook. The data obtained were analyzed through the SmartPLS program.

As a result of the analysis, it has been determined that there is social media marketing has positive influence on brand equity and purchasing intention.

In the light of the findings obtained from the study, it could be said that businesses can increase their brand value perception with planned and well-defined social media marketing strategies. With social media marketing, businesses can gain significant advantages in many areas such as brand loyalty, reduced advertising expenses and increased profitability, access to a large consumer audience and altered brand attitudes into purchasing behavior.
\end{abstract}

Keywords: Social Media Marketing, Brand Equity, Purchase Intention

JEL codes: M31, M37, M39

Citation/Atıf: Sağtaş, S., (2022). The effect of social media marketing on brand equity and consumer purchasing intention. Journal of Life Economics. 9(1): 21-31, DOI: 10.15637/jlecon.9.1.02 


\section{INTRODUCTION}

Today's technological developments and smart phones that allow internet access at any time have caused radical changes in all areas of life. Social media applications are Web 2.0 technologies at the forefront of high-tech innovations. According to 2020 data, the use of social media applications reached about 3.80 billion active users worldwide, and has grown by $9.2 \%$ compared to 2019 (wearesocial, 2020). It has been unavoidable that social media applications attract the attention of businesses. Applications, which were accepted as a socialization tool at first, have become a new communication and marketing tool over time. The fact that consumers spend more time in social media applications creates advantages and disadvantages for businesses. It has caused consumers to gain more power over the brands by expressing their comments and opinions about the products of the brands through social media (Gamboa and Gonçalves, 2014). Businesses had to develop special social media strategies as comments and peer reviews affected consumer purchase intention (Hutter et al.., 2013). A consumer-oriented approach is an important issue in modern marketing.. İt has led businesses to focus on social media marketing to understand consumer demands and needs (Arık, 2019).

Creating brand loyalty and brand value is important for businesses that start using the social media channel to reach their potential and existing customers (Hasan and Sohail, 2020). In this sense, social media has become a new brand value creation tool for business organizations. It is predicted that Facebook ads, which have the highest number of users, will reach 1.95 billion users worldwide (wearesocial, 2020).

The aim of this study is to evaluate the effect of social media marketing on consumer purchase intention. For this purpose, the relationship between social media marketing activities, perceived brand equity (brand loyalty, brand awareness, perceived quality, and brand associations) and purchase intention is discussed through the developed model. The study application was carried out with Facebook users, the social media application with the highest number of users.
In this study, the investigation of how social media activities affect consumer decisions will contribute to the literature. At the same time, it is predicted that it will guide the strategies business leaders develop for businesses that carry out social media marketing activities on Facebook.

\section{LITERATURE}

\subsection{Social Media Marketing}

Social media is based on Web 2.0 technologies and contains web-based applications that users create and share contents such as news, photos, audio, and videos through their own profiles. (Howard and Parks, 2012). Although it differs according to the purposes of use, it is based on creating personalized pages, sharing thoughts and messages, and communicating with others (Duffett, 2017). Wikis, blogs, social networks, forums and podcasts can be given as examples of the main social media applications where simultaneous content sharing is carried out. Features that distinguish social media sites from other websites include grouped personal profiles as online connection, joining online groups, and content sharing (Kim, Jeong and Lee, 2010). Users can communicate with the people in this application by creating a social media profile with the settings they have determined. Especially in these online applications, which can be integrated with other technologies, users can easily reach the contacts in the phone book and mailing list. At the same time, they have the opportunity to create live messaging and discussion forms thanks to the groups and pages created by users with common interests. Unlike traditional websites, users can share their own content on one platform on other platforms owing to the integration of social networks (İşlek, 2012).

Social media applications have affected the way of doing business as well as changing the way of communication between people. Social media platforms have become a new marketing channel for businesses as consumers use these platforms extensively (So, King and Sparks, 2014). It has been unavoidable for businesses desiring to interact with their consumers without the restrictions of time and place. Businesses use social media to reach current and potential customers, 
create brand awareness, provide information, and increase sales. (Stokes, 2013).

Social media marketing aims, in its most general sense, to promote the brand or products through online social channels (Barefoot and Szabo, 2010). Weinberg (2009), social media marketing has been defined as a process in which brands advertise their products or services through social channels and increase brand awareness; allowing them to interact and communicate with a very large audience compared to traditional advertisements. Businesses can perform direct marketing, promotion and sales activities by using social media marketing. In particular, consumers who actively use social media follow the experiences shared by other users and search for information before purchasing a product. Businesses that want to establish a close relationship with their consumers and provide positive feedback about the brand reach their consumers directly through social media marketing (Parker, 2010).

O'Brien and Terschluse (2009) describe the social media marketing process as a circular cycle of listening, measuring, connecting, and optimizing. In listening, the first step of social media marketing, businesses can access word and hashtag analysis data written over social media using tracking software such as Google Alert. In the measurement phase, the data obtained are divided into groups according to their purpose and categorical information is obtained. In this way, companies can access strategic information that will guide their actual marketing activities. Engagement is the stage where the data obtained by the companies provides solution generation and consumer satisfaction. In the final stage of optimization, businesses ensure customer loyalty through all the activities they have achieved in the direction of listening, measuring and connecting in line with their social media marketing strategies. After this stage, strong bonds are established with consumers through consumer loyalty rewarding activities. Businesses begin to develop and implement the final marketing strategy to reach a satisfied and broad consumer base (İşlek, 2012).

There are different views on the dimensions of social media activities in the literature. In their study on luxury brands, social media activities are grouped under five dimensions: interaction, knowledge, personalization, trending, and word of mouth (Kim an Ko, 2012). Similarly, Yadav and Rahman (2017) examined social media activities under five dimensions. In another study, purchase intention was added in addition to these five dimensions. (Koivulehto, 2017). Advertising is among the most important tools in which businesses interact with their consumers in social media marketing (Jo, 2013). In this context, it is important to add advertising to social media activities (Alalwan et al.,2017). Bilgin (2018) included social media activities in his study. One of the most important components that affects perception of followers in social media in a possitive way and increases the continuity of follow-up is entertainment (Kang, 2005). When a user has positive feelings about the brand or product, they can share this information with other users and positively affect their purchase intention (Dobele et al., 2007). Due to the structure of social media that allows easy communication and information sharing, interaction has an important place in marketing activities. This mutual interaction is not limited to consumers only. At the same time, companies can quickly communicate with their consumers and provide detailed information about the product or service (Maoyan , 2014). This rapid flow of information is also directly related to another component, the dimension of trending (Godey et al.,2016). Advertising is of great importance in social media marketing. Compared to traditional media channels, businesses can announce their advertisements, product information and promotions to a wider audience at less cost (Bilgin, 2018). Thanks to the social media sharing analysis carried out, it can use personalized sales strategies. Businesses can offer products and content according to the consumer's interest with personalization (Wind and Rangaswamy, 2001). All these social media activities affect the consumer's perception of brand value and purchase intention.

\subsection{Brand Equity}

In today's conditions, where competition continues to increase rapidly, businesses give more 
importance to branding in order to create a sustainable competitive advantage and to be distinguished by consumers. By using the advantages provided by social media channels, consumers can learn more about products and compare alternative brands. Among these brands, they tend to prefer the ones that make the most difference and that they like. Brand value is expressed as an added value that is added to a product or service (Farguhar, 1989), has an important place in the consumer-based marketing approach. Consumer-based brand value is a set of assets and liabilities that increase/ decrease the value of a product or service, connected with the name or symbol of a brand. (Aaker, 1991). Brand equity does not only include the resources that the consumer is ready to pay for the brand but also intangible resources such as the general attitude and perspective developed towards the brand (Uzunkaya and Yükselen, 2020).

Businesses that create brand value gain competitive advantage against the promotion activities of other competitors (Baalbaki and Guzman, 2016). Brand equity is explained in four dimensions: brand awareness, loyalty, connotation and perceived quality (Aaker,1991). Konecik and Gartner (2007) explained brand value with a model in which the brand image was included.

Brand awareness is when the consumer recognizes the brand and distinguishes it from other brands (Kim, Jeong and Lee, 2010; Aaker, 1991). Brand awareness is explained by two basic elements; brand recognition and brand recall. Brand recall is seen as the ability of a consumer who sees a product category to remember the brand, while the ability of consumers to recognize a product that has any of the characteristics of the brand is explained as brand recognition. (Hoeffler and Keller, 2002). It is known that high brand awareness positively affects brand preference and purchase intention (Aji, Nadhila and Sanny, 2020).

Brand loyalty is expressed in the fact that a consumer consistently buys the same brand, despite the presence of other brands.. It refers to the fact that the consumer performs the act of repurchasing faithfully, even if the brand differs in price and product features (Empon, Loy and Weiss,
2015). Here, consumers establish a connection with the brand through the positive emotions they develop. Positive thoughts about a brand lead to consumer's commitment to the brand (Sohail, Hasan and Sohail, 2020). Increasing the number of businesses offering similar products in a competitive environment increases the importance of brand loyalty. Consumers with brand loyalty also attract potential consumers by sharing their brand experiences with their close circles and recommending the brand. Such brand loyalty plays an important role in expanding the consumer base for businesses (Yoo, Donth and Lee, 2000).

Brand associations, with its most general definition, are the relationship that consumers have with the brand in their minds. Iversen and Hem (2008) define brand association as the color, type, shape, and features that are perceived differently from other brands that occur in the mind of the consumer when the brand is heard. These associations may consist of the consumer's experiences with the brand, as well as from secondary sources such as advertising word of mouth (Önen, 2018).

Perceived quality is a subjective perception and is a perception of excellence or superiority belonging to the brand (Aaker, 1991). The consumer makes an evaluation with both the general abstract feelings of a brand and the tangible features of the product. It is possible to say that the subjective evaluation formed as a result of this evaluation made by the consumer is different from the real or objective evaluation (Onurlubaş, 2018). Sanyal and Datta (2011) state that high perception of quality has a positive effect on the growth of sunday share of enterprises.

\section{METHOD}

\subsection{Research Model and Hypotheses}

This study is a quantitative and cross-sectional study and aims to reveal the effect of social media marketing on brand value and purchase intention. Cross-sectional research is the type of research in which the study data covers a certain period of time and constitutes a large part of social science research. 
Social media applications allow businesses to interact at a low cost without creating time and space constraints. This two-way interaction is important for consumers about their brand thinking and attitudes. Aji, Nadhila and Sanny (2020) have concluded that social media marketing activities has significant effect on on Instagram and brand equity in their study. Similarly, Martin and Todorov (2010) found that social media personalization has a significant effect on brand equity and brand loyalty. Park (2018), in his study in the airway industry, express that being a trend from social media marketing activities is the most important marketing dimension and has a significant impact on brand awareness. In the light of this information, H1 hypothesis was developed.

$\mathbf{H}_{1}$ : SMMA has a positive effect on brand equity.

Businesses that seek to have a greater say on consumer purchasing behavior with their marketing strategies closely follow technological developments and consumer trends. Consumer purchasing behavior is a complex process that is shaped by many factors such as needs, motives, personal characteristics and brand attitude. Nowadays, social media applications are important for businesses that want to shape consumer purchasing processes (Albors, Ramos and Herves, 2008 ). Hutter et al., (2013) stated that there is a significant relationship between the social media marketing activities of brands and their purchase intention in their study within the scope of the facebook application. Similarly, Zhu and Zhang (2010) emphasize that social media marketing has a positive effect on the sales performance of brands in their study. In another study (Akgün, 2020), it has been determined that the marketing activities of brands through social media have a positive relationship on purchase intention

In this context, $\mathrm{H} 2$ hypothesis was developed.

$\mathbf{H}_{2}$ : SMMA has a positive effect on purchase intention.

Today, it is possible for businesses to differentiate from their competitors, gain competitive advantage and place them in the minds of consumers with branding. Businesses that offer brand-based services have the ability to create a strong brand prestige by establishing strong bonds with their consumers (Perry and Wisnom, 2003). At the same time, with the strong brand they have created, they can add value to the products and services they offer to their consumers. Laksamana (2018) states that consumers with brand loyalty have a high repurchase intention. Similarly, studies in related literature (Aaker, 1991; Chang and Liu, 2009; Vinh and Huy, 2016) show that there is a significant relationship between brand equity and purchase intention.

In this context, $\mathrm{H} 3$ hypothesis was developed.

$\mathbf{H}_{3}$ : Brand Equity has a positive effect on purchase intention.

\subsection{Data Collection Method and Analysis}

A questionnaire consisting of two parts was used in the research. in the first section, there are 26 questions related to social media marketing activities, brand value and purchase intention. 5-point Likert-type scale was applied (5- I completely agree... 1-I completely disagree). The items were taken from Kim and Ko (2012) and Bilgin's (2018) studies with five-dimensional social media marketing activities: personalization, advertising, entertainment, trend and interaction. In the brand value scale consisting of four dimensions; Aaker's (1996) questions were used to determine perceived brand quality and brand loyalty, Seo and Park (2018) search provided for brand awareness, Park et al. (2019). In the second part of the questionnaire, there are 4 items prepared to find out the demographic characteristics of the participants and the duration of their use of social media. Data collection was carried out online. Analysis of the research data was conducted through the Smart PLS program. $\mathrm{p} \leq 0.05$ value was accepted as statistical significance level in all tests.

\subsection{Sampling Group}

The main mass of this study consists of users who live in Adana, have a facebook account and actively follow any brand profile on Facebook. Purposeful sampling, which is one of the non-probabilistic sampling methods, was used to determine the research participants. This method was preferred because it allows to include 
people with specified characteristics and comply with the research problem (Şahin and Gürbüz, 2014). In this context, the questionnaire was prepared online through Google forms and was carried out with 227 participants who voluntarily participated in the research. Information about the participant characteristics is presented in Table 1.

Table 1 displays participants' gender, educational attainment, time spent on browsing facebook and time spent on other social media platforms. More females (\%66.1) than males (\%33.9) participated in the study. In terms of educational attainment university graduates makes up the largest group (\%63). While participants with elementary education makes up one third of the total participants (\%29.9), high school graduates are the least participating group (\%7.5).

According to the time spent on Facebook during the day, $62.6 \%$ of the participants revealed that they spent 30 minutes or less time on facebook. Participants spending an hour of time on facebook during the day makes up $19.4 \%$ of the sample, while participants spending more than an hour makes up approximately $\% 16$ of the participants.

\section{FINDINGS}

In this section, the reliability analyses of the scales used in the study and the hypothesis tests created based on the literature in accordance with the purpose and model of the study are included. The data obtained in the study were analyzed through the SmartPLS program.

\subsection{Validity and Reliability Analysis of Scales}

Prior to the analyses, validity and reliability studies were conducted for the scale. internal consistency reliability and convergent validity coefficients were determined for validity and reliability. Cronbach's Alpha and CR=Composite Reliability coefficients were used for internal consistency reliability, and the mean variance (AVE=Subtracted Mean Variance) values explained by factor loads were used to determine convergent validity. in the studies, the factor load and reliability coefficients were expected to be $\geq 0.70$, and the average variance described was expected to be $\geq 0.50$. The reliability and validity results are shown in Table 2. In this study two dimensions, advertising and customization came out as compenents of SMMA. Similarly, Akgün

Table 1. Information About Participants

\begin{tabular}{|c|c|c|c|}
\hline & & Number (n) & Percent (\%) \\
\hline \multirow{3}{*}{ Gender } & Woman & 150 & 66,1 \\
\hline & Man & 77 & 33,9 \\
\hline & Total & 227 & 100 \\
\hline \multirow{4}{*}{ Educational Status } & $\begin{array}{l}\text { Primary } \\
\text { education }\end{array}$ & 67 & 29,5 \\
\hline & High school & 17 & 7,5 \\
\hline & University & 143 & 63,0 \\
\hline & Total & 227 & 100 \\
\hline \multirow{7}{*}{ Time spent on Facebook per day } & $\begin{array}{l}30 \text { min and } \\
\text { less }\end{array}$ & 142 & 62,6 \\
\hline & 1 hour & 44 & 19,4 \\
\hline & 2-3 hours & 28 & 12,3 \\
\hline & 4 hours & 8 & 3,5 \\
\hline & 5 hours & 2 & 0,9 \\
\hline & $\begin{array}{l}6 \text { hours and } \\
\text { more }\end{array}$ & 3 & 1,3 \\
\hline & Total & 227 & 100 \\
\hline \multirow{7}{*}{$\begin{array}{l}\text { Total time spent on other social } \\
\text { media pages per day }\end{array}$} & $\begin{array}{l}\begin{array}{l}\text { Less than } 1 \\
\text { hour }\end{array} \\
\end{array}$ & 75 & 33,0 \\
\hline & 2-3 hours & 81 & 35,7 \\
\hline & 4 hours & 21 & 9,3 \\
\hline & 5 hours & 27 & 11,9 \\
\hline & 6 hours & 4 & 1,8 \\
\hline & $\begin{array}{l}7 \text { hours and } \\
\text { more }\end{array}$ & 19 & 8,4 \\
\hline & Total & 227 & 100 \\
\hline
\end{tabular}


(2020) defined SMMA as two dimensional construct ( liking and effectiveness) in her study. Another study in which SMMA compenents were determined as two dimensional was that Demirci and Arik (2020).

The Cronbach Alpha coefficients of the scales are between 0.761 and 0.932; Since the CR coefficients are between 0.768 and 0.881 , it is accepted that the internal consistency reliability is sufficient. According to the values in the table, it is seen that the factor loads are between 0.680 and 0.904. It is stated that the factor loads should be $\geq 0.708$. If the $A V E$ or $C R$ values are below the threshold value, they suggested decoupling exp- ressions with factor loads between 0.40 and 0.70 from the model. it recommends that expressions with a factor load below 0.708 should not be excluded from the measurement model (Hair et al.,2014).

Factor loads of the scales were between 0.680 and 0.904; Since the AVE values were between 0.522 and 0.712 , accordingly, it can be said that convergent validity has been achieved.

\section{Research Model and Results}

In the research, the structural equation model created to test the hypotheses is shown in Figure-1.

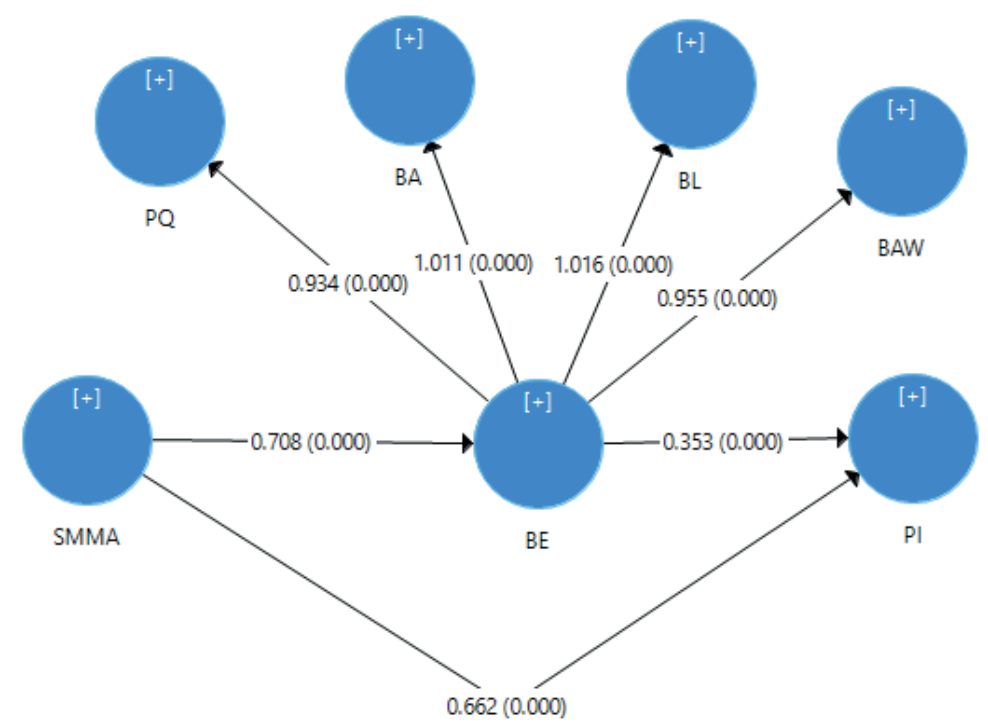

Figure 1. Structural Equation Model

Table 2. Measurement Model Results

\begin{tabular}{|c|c|c|c|c|c|}
\hline Variable & Item & $\begin{array}{l}\text { Factor } \\
\text { Loads }\end{array}$ & $\begin{array}{l}\text { Cronbach } \\
\text { Alfa }\end{array}$ & CR & AVE \\
\hline \multirow{4}{*}{$\begin{array}{c}\text { Social Media } \\
\text { Marketing Activities } \\
\text { (SMMA) } \\
\text { Advertisement (A) } \\
\text { Customization (C) }\end{array}$} & $\mathrm{A} 1$ & 0.708 & \multirow{4}{*}{0.814} & \multirow{4}{*}{0.813} & \multirow{4}{*}{0.522} \\
\hline & $\mathrm{A} 2$ & 0.680 & & & \\
\hline & $\mathrm{C} 1$ & 0.776 & & & \\
\hline & $\mathrm{C} 2$ & 0.723 & & & \\
\hline \multirow{11}{*}{$\begin{array}{c}\text { Brand Equity (BE) } \\
\text { Percieved Quality (PQ) } \\
\text { Brand Assocation (BA) } \\
\text { Brand Loyalty (BL) } \\
\text { Brand Awareness } \\
\text { (BAW) }\end{array}$} & PQ1 & 0.815 & \multirow{11}{*}{0.932} & \multirow{3}{*}{0.856} & \multirow{3}{*}{0.668} \\
\hline & PQ2 & 0.664 & & & \\
\hline & PQ3 & 0.948 & & & \\
\hline & BA1 & 0.861 & & \multirow{2}{*}{0.768} & \multirow{2}{*}{0.625} \\
\hline & BA2 & 0.713 & & & \\
\hline & BL1 & 0.793 & & \multirow{3}{*}{0.881} & \multirow{3}{*}{0.712} \\
\hline & BL2 & 0.874 & & & \\
\hline & BL3 & 0.862 & & & \\
\hline & BAW1 & 0.825 & & \multirow{3}{*}{0.859} & \multirow{3}{*}{0.671} \\
\hline & BAW2 & 0.904 & & & \\
\hline & BAW3 & 0.717 & & & \\
\hline \multirow{4}{*}{$\begin{array}{l}\text { Purchase Intentions } \\
\text { (PI) }\end{array}$} & PI1 & 0.764 & \multirow{4}{*}{0.855} & \multirow{4}{*}{0.853} & \multirow{4}{*}{0.522} \\
\hline & PI2 & 0.667 & & & \\
\hline & PI3 & 0.740 & & & \\
\hline & PI4 & 0.791 & & & \\
\hline
\end{tabular}


Partial least squares path analysis (PLS-SEM) was used to analyze the model of the study. Regarding the research model; PLS algorithm used was for calculating linearity, path coefficients, R2 and effect size (f2'); and Blindfolding analysis was run to calculate the predictive power (Q2). In order to evaluate the significance of the PLS path coefficients, $t$-values were calculated by taking 5000 subsamples from the bootstrapped sample.

VIF, R2, f2 and Q2 values are presented in Table 3.

When the VIF (Variance Inflation Factor) values between the variables were examined, it was figured that there was no linearity problem between the variables since the values were below the threshold value of 5 . When the $\mathrm{R} 2$ values obtained from the model were examined, it was determined that $50 \%$ of the brand value and $89 \%$ of the purchase intention were explained. ). Having an effect size coefficient (f2) of 0.02 and above is low; 0.15 and above is moderate; A score of 0.35 and above is considered high (Cohen, 1988). Sarstedt et al. (2017), stated that it is not possible to talk about an effect in cases where the coefficient is below 0.02 . When the effect size coefficients (f2) are examined, it has been observed that social media marketing has a high impact on brand value and purchase intention.

It was found that SMMA had a statistically significant effect on brand value $(\beta=0.708 ; p<0.01)$. Based on these findings, hypothesis 1 of the research was supported. It was found that SMMA had a statistically significant effect on purchase intention $(\beta=0.662 ; p<0.01)$. In relation to these findings, research hypothesis 2 was supported. It was understood that brand value has a statistically significant effect on purchase intention $(\beta=0.353 ; p<0.01)$. Based on these findings, hypothesis 3 of the research was supported.

\section{CONCLUSION AND RECOMMEN- DATIONS}

Social media applications are adding more people to their users lists every day. Social media has become an important in our daily lives and it becomes highly influential in shaping consumer behavior. Social media pages make it possible to reach a large consumer mass easily and quickly, and have the capability to attract the attention of businesses in a short time.

Covid 19 pandemic let to a development of new digital consumer profiles. The curfews imposed by the governments to prevent the spread of the epidemic sparked off people to find new ways to connect with others, including the businesses. It is known that consumers, who tend to shop more online due to the restrictive conditions and risk of contamination increase their social media usage times. This situation has brought along the opportunity for brands to follow their consumers closely by using the right social marketing strategies. In this context, it is important to understand the use of social media, which is widely used by consumers, in terms of marketing activities and consumer behavior. The purpose of this research is to investigate the effect of marketing activities in social media on perceived brand value and purchase intention. For this purpose, an online survey was conducted with 227 users using Facebook, one of the most popular social

Table 3. Research Model Result

\begin{tabular}{|c|c|c|c|c|c|}
\hline \multicolumn{2}{|c|}{ Variable } & VIF & $\mathbf{R}^{\mathbf{2}}$ & $\mathbf{f}^{\mathbf{2}}$ & $\mathbf{Q}^{\mathbf{2}}$ \\
\hline SMMA & Brand Equity & 1000 & 0.497 & 0.989 & 0.226 \\
\hline $\begin{array}{c}\text { SMMA } \\
\text { Brand Equity }\end{array}$ & Purchase Intentions & 1989 & 0.894 & 0.066 & 0.476 \\
\hline
\end{tabular}

Table 4. Araştırma Modeli Katsayıları

\begin{tabular}{|c|c|c|c|c|c|}
\hline \multicolumn{2}{|c|}{ Variable } & $\boldsymbol{\beta}$ & SS & t value & p \\
\hline SMMA & Brand Equity & 0.708 & 0.061 & 11.581 & 0.000 \\
\hline SMMA & Purchase Intention & 0.662 & 0.071 & 9.296 & 0.000 \\
\hline Brand Equity & Purchase Intention & 0.353 & 0.083 & 4.234 & 0.000 \\
\hline
\end{tabular}


media applications in the world.

According to the result of the study, marketing activities via social media have a positive effect on brand value. Similarly, Laksamana (2018) concluded in his study that social media marketing has a significant impact on consumer loyalty. and brand value perception. Zollo et al. (2020) state that social media marketing activities are a good tool to create a positive brand experience for the consumer. Also, consumers who interact with the brand on social media tend to show high quality perception and brand loyalty to the brand due to positive brand associations (Chang, Yu and Lu, 2015). In the research, it was concluded that social media marketing activities has positive affect on purchase intention. This result supports the studies conducted by Kim and Ko (2010) and Yadav and Rahman (2017). Similarly, Orel and Arik (2020) emphasized that being informative and entertaining, which is one of the dimensions of social media marketing, has a positive effect on consumers' purchase intention. Social media tools can affect the decision-making process in purchasing behavior by increasing the interaction of the consumer with the brand (Constantinides and Stagno, 2011). In this context, it is possible for brands that use social media effectively to increase their existing consumer base. Another important factor affecting purchasing behavior is brand equity. In the study, it was concluded that brand value has a positive effect on purchasing intention by supporting the literature. Yoo et al., (2000) concluded in their research that high brand equity increases the intention to buy. Brand loyalty, brand connotations, perceived quality and brand awareness, which are the sub-dimensions of brand equivalence, directly affect purchasing intention (Wright, Williams and Byon, 2017).

In the light of the findings from this study, it is possible to assert that businesses can increase their brand value perception with planned and well-defined social media marketing strategies. Businesses can strengthen their competitive position with advantages such as increasing brand value and expanding sales volume with consumer interaction developed through social media. It is also observed that consumers use social media extensively and length of time they spend affect their consumption style. In this context, considering that social media has important effects on consumers' purchasing and brand perception, it may be beneficial to direct promotional activities to these channels. It can be suggested that future research on this subject should be implemented in different social media applications so that comparisons could be made between studies that vary on the basis of samples and types of social media channels.

\section{REFERENCES}

AAKER, D. A. (1991). Managing Brand Equity: Capitalizing on the Value of a Brand Name. New York: The Free Press.

ALALWAN, A. A., RANA, N. P., DWIVEDI, Y. K. AND ALGHARABAT, R. (2017). Social media in marketing: A review and analysis of the exi sting literature. Telematics and Informatics, 34(7), 1177-1190.

AJI, P., NADHILA, V., \& SANNY, L. (2020). Effect of social media marketing on Instagram towards purchase intention: Evidence from Indonesia's ready-to-drink tea industry. International Journal of Data and Network Science, 4(2), 91-104.

AKGÜN, Z. (2020). Sosyal medya pazarlama aktivitelerinin marka değeri, tüketici yanıtları ve satın alma niyetine etkisi: hızlı moda markalarına yönelik bir araştırma. Business \& Management Studies: An International Journal, 8(5), 4211-4240.

BAALBAKI, S., \& GUZMÁN, F. (2016). A consumer-perceived consumer-based brand equity scale. Journal of Brand Management, 23(3), 229-251.

BAREFOOT, D., AND J. SZABO. (2010). Friends with benefits: A social media-marketing handbook. San Francisco: No Starch Press.

CHANG, Y. T., YU, H., \& LU, H. P. (2015). Persuasive messages, popularity cohesion, and message diffusion in social media marketing. Journal of Business Research, 68(4), 777-782.

CONSTANTINIDES, E., \& ZINCK STAGNO, M. C. (2011). Potential of the social media as instruments of higher education marketing: a segmentation study. Journal of Marketing for Higher Education, 21(1), 7-24.

DOBELE, A., LINDGREEN, A., BEVERLAND, M., 
VANHAMME, J., \& VAN WIJK, R. (2007). Why pass on viral messages? Because they connect emotionally. Business Horizons, 50(4), 291-304.

DUFFETT, R. G. (2017). Influence of social media marketing communications on young consumers' attitudes. Young Consumers.18 (1), 19-39.

FARQUHAR, P. H. (1989). Managing brand equity. Marketing research, 1(3).

GAMBOA, A. M., and H. M. GONC, alves, (2014). Customer loyalty through social networks: Lessons from Zara on Facebook. Business Horizons 57 (6):709-17.

GOdey, B., MANThioU, A., PEDERZOLI, D., JOONASROKKA, AIELLO, G., DONVITO, R. AND SINGH, R. (2016). Social media marketing efforts of luxury brands: Influence on brand equity and consumer behavior. Journal of Business Research, 69(12), 5833- 5841.

HAIR, J.F., TOMAS, G., HULT, M., RINGLE, C.M., SARSTEDT, M. (2014), A Primer on Partial Least Square Structural Equations Modeling (PLS-SEM), Los Angeles: Sage.

HASAN, M., \& SOHAIL, M. S. (2020). The Influence of Social Media Marketing on Consumers' Purchase Decision: Investigating the Effects of Local and Nonlocal Brands. Journal of International Consumer Marketing, 1-18.

HOEFFLER, S., \& KELLER, K. L. (2002). Building brand equity through corporate societal marketing. Journal of Public Policy \& Marketing, 21(1), 78-89.

HOWARD, P. N., \& Parks, M. R. (2012). Social media and political change: Capacity, constraint, and consequence. Journal of Comminucation, 62 (2), 359-362.

HUTTER, K., J. HAUTZ, S. DENNHARDT, AND J. FULLER (2013). The impact of user interactions in social media on brand awareness and purchase intention: The case of MINI onFacebook. Journal of Product \& Brand Management 22 (5/6):342-51.

IVERSEN, N. M., \& Hem, L. E. (2008). Provenance associations as core values of place umbrella brands: A framework of characteristics. European Journal of Marketing, 42(5), 603-626.

İŞLEK, M. S., (2012). Sosyal medyanın tüketici davranışlarına etkileri. Yüksek Lisans Tezi. Karamanoğlu Mehmetbey Üniversitesi Sosyal Bilimler Enstitüsü, Karaman.

JO, S. A. (2013). Impact of Company's SNS Marketing Activities on Perceived Value and Customer's Loyalty: Focusing on Facebook. Master Thesis, Seoul: Hong-IK
University.

KANG, M. J. (2005). A Study on the Effect of Features of Brand Community Using One person Media on Consumers. Master Thesis, Seoul: Seoul National University.

KIM W., JEONG, O. R. \& LEE, S. W. (2010). On social web sites. Information Systems, 35(1), 215-236.

KIM, A. J., \& KO, E. (2010). Impacts of luxury fashion brand's social media marketing on customer relationship and purchase intention. Journal of Global Fashion Marketing, 1(3), 164-171.

KONECNIK, M. \& GARTNER, W. C. (2007). Customer-based brand equity for a destination, Annals of tourism research, 34(2), 400-421.

KOIVULEHTO, E. I. (2017). Do social media marketing activities enhance customer equity? A case study of fast-fashion brand Zara. Master Thesis, Helsinki: Aalto University.

LAKSAMANA, P. (2018). Impact of social media marketing on purchase intention and brand loyalty: Evidence from Indonesia's banking industry. International Review of Management and Marketing, 8(1), 13-18.

MAOYAN, Z. SANGYANG.(2014). Consumer purchase intention research based on social media marketing. International Journal of Business and Social Science, 5(10), 92-97.

O'BRIEN, K. \& TERSCHLUSE, C. (2009). Determining the Impact of Customer Relationships Social Media Measurement \& Analysis. Crimson Consulting Group, 4-10

OREL, F. D., \& ARIK, A. Sosyal Medya Pazarlamasının Tüketici Satın Alma Niyetine Etkisinin Teknoloji Kabul Modeli Aracılığıyla İncelenmesi. Erciyes Üniversitesi İktisadi ve İdari Bilimler Fakültesi Dergisi, (57), 239-266.

PARK, W.S. (2013). Effects of Band Equity on Behavioral Intention in Food Service Franchising Businesses. Doctoral dissertation, Kyonggi University.

SEO, W.S., \& KIM, M.K., (2003). A study on the effect of consumer behavior intention of brand equity in hotel. Korean Journal of Tourism Research, 18(2), 111-127.

SO, K. K. F., KING, C., \& SPARKS, B. (2014). Customer engagement with tourism brands: Scale development and validation. Journal of Hospitality and ourism Research, 38(3), 304-329.

SOHAIL, M. S., HASAN, M., \& SOHAIL, A. F. (2020). The Impact of Social Media Marketing on Brand Trust and Brand Loyalty: An Arab Perspective. International Journal of Online Marketing (IJOM), 10(1), 1531.

STOKES, R. (2013). eMarketing: The Essential Guide to 
Marketing in a Digital World, 5th ed., Quirk Education, Cape Town.

GÜRBÜZ, S., \& ŞAHIN, F. (2014). Sosyal bilimlerde araştırma yöntemleri. Ankara: Seçkin Yayıncılık.

UZUNKAYA, T., \& YÜKSELEN, C. (2020). Lüks giyim markalarında sosyal medya ilgilenimi, marka değeri ve marka tercihi ilişkisi üzerine bir araştırma. Öneri Dergisi, 15(53), 276-304.

WEARESOCIAL, (2020). We are social digital report. 23.04.2021 tarihinde https://wearesocial.com/ adresinden alınmıştır.

WEINBERG, T. (2009). The new community rules: Marketing on the social web. Development and Learning Organizations, 25(3), 3446

WIND, J., \& RANGASWAMY, A. (2001). Customerization: The next revolution in mass customization. Journal of interactive marketing, 15(1), 13-52.

WRIGHT, B. K., WILLIAMS, A. S., \& BYON, K. K. (2017). Brand marketıng via facebook: an investigation of the marketıng mix, consumer-based brand equity, and purchase intention in the fitness industry. Marketing Management Journal, 27(2), 131-142.

YADAV, M., \& RAHMAN, Z. (2017). Measuring consumer perception of social media marketing activities in e-commerce industry: Scale development \& validation. Telematics and Informatics, 34(7), 1294-1307.

YOO, B., DONTHU, N., \& LEE, S. (2000). An examination of selected marketing mix elements and brand equity. Journal of the Academy of Marketing Science, 28(2), 195211.

ZOLLO, L., FILIERI, R., RIALTI, R., \& YOON, S. (2020). Unpacking the relationship between social media marketing and brand equity: The mediating role of consumers' benefits and experience. Journal of Business Research, $117,256-267$

ZHU, F., ZHANG, X. (2010), Impact of online consumer reviews on sales: The moderating role of product and consumer characteristics. Journal of Marketing, 74(2), 133148. 